\title{
Effect of the phytosanitary treatment of seeds on the initial growth of upland rice
}

\section{Efeito do tratamento fitossanitário de sementes no crescimento inicial de arroz de terras altas}

\author{
Elvis Felipe ELLI'; Braulio Otomar CARON²; Velci Queiróz de SOUZA²; Gean Charles MONTEIRO³; \\ Elder ELOY ${ }^{4}$; Cleiton KORCELSKI ${ }^{5}$
} 1 Autor para correspondência - Engenheiro Agrônomo, Mestre em Agronomia, Doutorando em Engenharia de Sistemas
Agrícolas, ESALQ, Universidade de São Paulo, Departamento de Engenharia de Biossistemas, Av. Pádua Dias, 11, CEP
13418-900, Piracicaba/SP. elvisfelipeelli@usp.br
${ }^{2}$ Engenheiro Agrônomo, Dr., Professor da Universidade Federal de Santa Maria, Campus Frederico Westphalen/RS,
otomarcaron@yahoo.com.br; velciq@smail.ufsm.br
${ }^{3}$ Engenheiro Agrônomo, Mestrando em Agronomia, Faculdade de Ciências Agrárias (UNESP), Campus Botucatu/SP
gean.monteiro@yahoo.com.br
${ }^{4}$ Engenheiro Florestal, Dr. Professor da Universidade Federal de Santa Maria, Campus Frederico Westphalen/RS,
eloyelder@yahoo.com.br.
${ }^{5}$ Engenheiro Agrônomo, Mestre em Agronomia, Doutorando em Agronomia, Universidade de Passo Fundo/RS,
korcelski@gmail.com

Recebido em: 08-12-2014; Aceito em: 23-06-2016

\begin{abstract}
The initial growth of plants is a crucial period in the development cycle of the different crops of agricultural interest. This phase is the target of attack by different pests that drastically reduce this growth. Commonly, chemical pesticides are used in order to control the attack, but little has been elucidated about the effect of their contact with the seed. Therefore, the work aimed to evaluate the effect of the phytosanitary treatment of seeds on the initial growth of upland Oryza sativa L. For such, four seed treatments were tested (T1 - no seed treatment, T2 - fipronil + pyraclostrobin + thiophanate-methyl, T3 - thiamethoxam + carbendazim, thiram and T4 - imidacloprid + thiodicarb) in six evaluation periods (28, 35, 42, 49, 56 and 63 days after emergence). The design was a randomized block. The variables determined were dry mass of root, dry mass of shoot, root length, plant height, leaf area and chlorophyll content. The use of chemical treatments in upland rice seeds yielded positive effects against all morphological variables studied, except chlorophyll content. The treatment consisting of fipronil + pyraclostrobin + thiophanate-methyl provided greater increase of the morphological variables. The chemical treatments in seeds corresponded to a differentiation in the post-emergence vegetative development of seedlings for the characteristics of dry mass of root, dry mass of shoot, root length, plant height and leaf area, promoting greater initial growth of the crop in this period.
\end{abstract}

Additional keywords: fungicides; insecticides; Oryza sativa L.

\section{Resumo}

O crescimento inicial de plantas é período crucial no ciclo de desenvolvimento das diversas culturas de interesse agrícola. Essa fase é foco de ataque de distintas pragas que reduzem drasticamente esse crescimento. Comumente, defensivos químicos são utilizados com o objetivo de controlar o ataque, mas pouco se tem elucidado sobre o efeito do contato dos mesmos com a semente. De modo que o trabalho teve como objetivo avaliar o efeito do tratamento fitossanitário de sementes no crescimento inicial de Oryza sativa L. cultivadas em terras altas. Para tanto, foram testados quatro tratamentos de semente (T1 - ausência de tratamento de semente; T2 - fipronil + piraclostrobina + tiofanato-metílico; T3 - tiametoxam + carbendazim tiram, e T4 - imidacloprido + tiodicarbe) e seis períodos de avaliação (28; 35; 42; 49; 56 e 63 dias após a emergência). $O$ delineamento utilizado foi o de blocos ao acaso. As variáveis determinadas foram massa seca da raiz, massa seca da parte aérea, comprimento da raiz, altura de planta, área foliar e índice de clorofila. O uso de tratamentos químicos nas sementes de arroz de sequeiro proporcionou efeitos positivos, frente a todas as variáveis morfológicas estudadas, exceto no índice de clorofila. $\mathrm{O}$ tratamento composto por fipronil + piraclostrobina + tiofanato-metílico proporcionou maior incremento das variáveis morfológicas. Os tratamentos químicos em sementes corresponderam a uma diferenciação no desenvolvimento vegetativo em pós-emergência de plântulas, para as características massa seca da raiz, massa seca da parte aérea, comprimento da raiz, comprimento da parte aérea e área foliar, promovendo maior crescimento inicial da cultura neste período.

Palavras-chave adicionais: fungicidas; inseticidas; Oryza sativa L. 


\section{Introduction}

Rice (Oryza sativa L.) currently matches as one of the main food sources to the world's population (Jouki \& Khazaei, 2012; Liu et al., 2015), thus constituting, along with wheat (Triticum aestivum) and corn (Zea mays), the most produced and consumed food worldwide (Fan et al., 2010; Pan et al., 2016). Despite the increasing demand for food due to the sharp population growth, the FAO (Food and Agriculture Organization) points out that the increase in the world rice production does not meet yet the increase in the population (FAO, 2009).

In Brazil, the rice crop was the third most important crop in the 2012/2013 harvest, after soybean and corn, being characterized in most states as an upland crop and this cultivation system accounted for about $50 \%$ of the area cultivated with rice in the country (Mingotte et al., 2015). Only the state of Rio Grande do Sul conditioned $50 \%$ of the national area and $67 \%$ of the volume produced, so that the upland cultivation in the same was almost null (CONAB, 2013). Only in Rio Grande do Sul, the rice cultivation covers a large number of workers, generating a significant financial amount to the properties. Thus, rice production, besides being an important source of food, increases the income and provides work for much of the state's population (Menezes et al., 2013).

In this context, Villar \& Ferreira (2005) showed that although the upland rice has a low requirement of agricultural inputs, adding appropriate practices and using coherent technology, in order to provide the crop an adequate emergence and further vigorous early development, is essential for the plant to express its full productive potential.

Resulting from the action of soil and shoot pests, negative effects on seeds and/or young plants are common in the post-emergence period of the crop. However, alternatives such as the use of insecticides and fungicides via seed treatment showed satisfactory results (Martins et al., 2009; Silva et al., 2011). The chemical treatment of seeds is considered an important agricultural procedure that aims at efficiency in the control of pests and diseases occurring in the seeds, in order to reduce decreases in productivity caused by reductions in the final plant population and injuries in the post-emergence of seedlings. Moreover, the seed treatment has low cost to the agricultural production and low environmental impact due to localized application, which results in reducing the amount of these products by acreage (Santos et al., 2010; Cunha et al., 2015).

After the sowing, intrinsic characteristics of the chemical treatment, such as low vapor pressure and water solubility, allow these products to be detached from the seeds, being absorbed by the root system of the seedling, subsequently providing the plant an extended period of protection against pests and diseases in the soil and shoots (Salgado \& Ximenes, 2013).
Insecticides and fungicides are usually conceptualized regarding the efficiency in the control of pests and diseases, notwithstanding the direct physiological effects on seeds are still poorly understood. In studies conducted in order to observe the direct physiological effects of applying chemical treatment in seeds, Pereira Filho et al. (2008) observed positive implications on the physiological aspect of bean seedlings (Phaseolus vulgaris), resulting from the application of fipronil (Standak®) and thiamethoxam (Cruiser®).

Nonetheless, bean is a plant belonging to the family Fabaceae, with nutritional reserves in the cotyledons. In the case of rice, the seed is a fruit called caryopsis, surrounded by two glumes, lemma and palea. The caryopsis is formed by the embryo, seed coat, pericarp and endosperm, the latter structure being the seed storage tissue, since it contains parenchymal cells rich in starch. The outermost layer of this structure is called the aleurone, consisting of one to two cells in the ventral and lateral regions of the caryopsis and four to six cells in the dorsal region, which is opposite to the embryo. These cells contain a high content of protein and absence of starch. It is in the aleurone layer that the germination process is triggered after the imbibition of water through the scutellum, characterized as a modified leaf already present in the embryo (Fornasieri Filho \& Fornasieri, 2006).

In this context, the study of the beneficial effects, both regarding the protection and physiology of plants, resulting from the application of fungicides and insecticides in upland rice seeds is still not widespread. Thus, this study aimed to evaluate the effect of seed treatment on the morphophysiological variables during the early development of upland rice (Oryza sativa L.).

\section{Material and methods}

The experiment was carried out in the geographical coordinates of $27^{\circ}-23^{\prime} 48^{\prime \prime} \mathrm{S}, \quad 53^{\circ} 25^{\prime} 45^{\prime \prime} \mathrm{W}$, with an altitude of 490 meters. According to the Köppen climate classification, the climate is Cfa, i.e., humid subtropical with an average annual temperature of $19.1^{\circ} \mathrm{C}$, varying with maximum of $38^{\circ} \mathrm{C}$ and minimum of $0{ }^{\circ} \mathrm{C}$. The soil of the experimental area belongs to the Passo Fundo mapping unit, located in the state of Rio Grande do Sul and classified as typic dystrophic Red Latosol, clayey, deep and well drained (Embrapa, 2006).

The experimental design was a randomized complete block, in a factorial $4 \times 6$, being four seed treatments (ST) and six periods of evaluation after seedling emergence (days after emergence - DAE), with three replications. Sowing of rice was held on $09 / 28 / 2011$, with a sowing depth of about three centimeters. On the basic fertilization, it was applied an equivalent to $200 \mathrm{~kg} \mathrm{ha}^{-1}$ of the formulated fertilizer NPK (10:20:20) and at 30 DAE (V5 stage - Escala 
Counce et al., 2000), it was applied $67.5 \mathrm{~kg} \mathrm{ha}^{-1}$ of nitrogen $(\mathrm{N})$.

No-till was adopted for soil preparation, vetch was the preceding crop. The experimental units consisted of five rows five meters long, spaced 0.45 meters. The useful plot was represented by the three core lines.

The cultivar used was Maravilha, grown in uplands and characterized as needle grain (long and thin). The weed control was performed weekly by manual weeding and 21 days after sowing, thinning was held aiming at a final population of 166 plants $\mathrm{m}^{-2}$. The period between sowing and emergence was eight days. It was established as emergence stage when $50 \%$ of the seedlings had their coleoptiles exposed by two centimeters above the soil surface.

Treatments were set in the following combinations: (T1) no seed treatment; (T2) fipronil (pyrazol) + pyraclostrobin (strobilurin) + thiophanate-methyl (benzimidazole) at the dose: $1 \mathrm{ml} \mathrm{kg}^{-1}$; (T3) thiamethoxam (neonicotinoid) at the dose: $0.5 \mathrm{ml} \mathrm{kg}^{-1}+$ carbendazim (benzimidazole), thiram (dimethyldithiocarbamate) at the dose: $0.5 \mathrm{ml} \mathrm{kg}^{-1}$ and (T4) imidacloprid (neonicotinoid) + thiodicarb (oxime methylcarbamate) at the dose: $1 \mathrm{ml} \mathrm{kg}^{-1}$. The application of the dose was carried out diluted into $2 \mathrm{ml}$ of water per $\mathrm{kg}$ seeds, directly on them, in both treatments, subsequently followed by agitation and homogenization in plastic bags for better distribution of products.

The evaluations were performed at intervals of seven days from 28 DAE. For being a short-cycle species (130 days), this sampling interval was used, according to the recommendations of Benincasa (2004).

The morphophysiological variables evaluated in the established periods were:

- Chlorophyll content (CHLOR): the quantification of the chlorophyll content was obtained using chlorophyll meter SPAD-502 (Soil Plant Analysis Development $(\AA)$, measuring as a reference the last fully expanded leaf of 10 plants in each subplot. Upon the issuance of the flag leaf, evaluations were conducted in the same. The final reading was given by the average of three leaf points: basal area, median and apex, according to the methodology used by Elli et al. (2013). The determinations were carried out from 10 to 12 a.m., under clear sky conditions.

- Leaf area (LA): determined with the aid of a leaf area integrator $\mathrm{LI} 3000 \mathrm{C} \AA$, expressed in $\mathrm{cm}^{2}$ plant $^{-1}$. The leaves of ten plants in each subplot were detached from the main stem and inserted on the treadmill of the equipment with subsequent measurement.

- Dry mass of root (DMR) and Dry mass of shoot (DMS): after determining the morphological variables, the plants were taken to a forced air oven, with an average temperature of $55^{\circ} \mathrm{C}$ until constant weight, $g$ (grams). This procedure was performed in all evaluation periods.

- Plant height $(\mathrm{PH})$ : with the aid of a graduated scale, it was carried out the measuring of the height of ten plants, featuring the distance, in $\mathrm{cm}$, from the ground level to the apex of the last fully expanded leaf. Upon the issuance of the flag leaf, the measurements were made up to the apex of it.

- Root length (RL), with the aid of a graduated rule, it was measured the length between the neck of the plant (at ground level) and the end of its longest root. The plants were collected through the making of trenches parallel to the cultivation line with the aid of a cutting shovel, in order to ensure full analysis of the root. This length was given in $\mathrm{cm}$ (centimeters).

The data were submitted to analysis of variance (ANOVA) using the software Statistical Analysis System ${ }^{\circledR}$ (SAS, 2000). The variables that showed significant differences by $F$ test $(p<0.05)$ were submitted to polynomial regression analysis (quantitative factor - periods) and Tukey test was performed when there were significnt differences by $t$ test (qualitative factor - seed treatments).

\section{Results and discussions}

According to the analysis of variance (Table 1), significant interactions were observed between ST and $\mathrm{DAE}$ for the variables DMR, DMS, RL, PH and LA. For the variable CHLOR there was no interaction $S T^{\star} D A E$, however there were effects regarding the DAE.

Table 1 - Analysis of variance of dry mass of shoot (DMS), dry mass of root (DMR), plant height (PH), root length (RL) chlorophyll content (CHLOR) and leaf area (LA) of upland rice under different seed treatments (ST) over the days after emergence (DAE) in the city of Frederico Westphalen - RS (2011).

\begin{tabular}{lcrrrrrr}
\hline \multirow{2}{*}{ Source of variation } & \multirow{2}{*}{ DF } & \multicolumn{7}{c}{ Mean Square } \\
\cline { 2 - 7 } & & DMS & DMR & PH & RL & CHLOR & \multicolumn{1}{c}{ LA } \\
\hline ST & 3 & $138.00^{*}$ & $68.82^{*}$ & $117.73^{*}$ & $44.75^{*}$ & $6.94^{\text {ns }}$ & $8226.75^{*}$ \\
DAE & 5 & $651.33^{*}$ & $352.28^{*}$ & $2560.56^{*}$ & $96.44^{*}$ & $172.53^{*}$ & $119636.34^{*}$ \\
ST*DAE & 15 & $26.17^{*}$ & $16.71^{*}$ & $23.13^{*}$ & $7.378^{*}$ & $5.52^{\text {ns }}$ & $2627.93^{*}$ \\
Mean & - & 8.33 & 6.49 & 30.76 & 9.16 & 32.86 & 171.74 \\
R $^{2}$ & - & 0.94 & 0.91 & 0.95 & 0.89 & 0.71 & 0.93 \\
CV $(\%)$ & - & 31.81 & 42.05 & 12.31 & 14.86 & 8.93 & 21.79 \\
\hline
\end{tabular}

* Significant at 5\% error probability; ns: not significant at 5\% error probability; $\mathrm{R}^{2}$ : coefficient of determination; DF: degrees of freedom; CV: coefficient of variation. 
By meeting these statements, the results presented in Table 2 demonstrated reductions for almost all the morphophysiological variables in $T 1$, when there was no application of seed treatment. Pereira et al. (2002) stated that the rice crop can be attacked by pathogenic fungi at any stage of its production cycle, thus reducing its vigor.

The shoot of the plants is intrinsically responsible for conducting photosynthesis, physiological process occurring mainly in the leaves, where the chloroplast density is greater and, consequently, is also greater the amount of photosynthetic pigments. Hence, the rapid initial growth of this organ provides the plants higher production of photoassimilates at the beginning of their cycle, determining appropriate further development. At 63 DAE of the seedlings, there was a significant increase in the height of plants from seeds subjected to applications of the treatment thiamethoxam + carbendazim + thiram (T3), while the treatment fipronil + pyraclostrobin + thiophanate-methyl (T2) did not show a significant difference in relation to the treatment with absence of agrochemicals. The seed treatment imidacloprid + thiodicarb (T4) showed no increases in plant height for the rice crop (Table 2).

Table 2 - Effect of the different seed treatments on the variables dry mass of shoot (DMS), dry mass of root (DMR), plant height $(\mathrm{PH})$, root length $(\mathrm{RL})$ and leaf area $(\mathrm{LA})$ in upland rice, in the city of Frederico Westphalen-RS (2011).

\begin{tabular}{|c|c|c|c|c|c|c|c|c|c|c|c|c|c|}
\hline \multirow{2}{*}{ Variables } & \multirow{2}{*}{ Treatments } & \multicolumn{12}{|c|}{ Periods (DAE) } \\
\hline & & 28 & & 35 & & 42 & & 49 & & 56 & & 63 & \\
\hline \multirow{4}{*}{ DMS (g plant ${ }^{-1}$ ) } & T1 & 0.64 & a & 1.08 & a & 1.41 & $\mathrm{~b}$ & 4.18 & C & 4.22 & $\mathrm{~b}$ & 8.60 & $\mathrm{~b}$ \\
\hline & T2 & 1.24 & a & 3.12 & a & 6.83 & a & 14.51 & a & 14.72 & $\mathrm{a}$ & 22.33 & a \\
\hline & T3 & 1.27 & a & 1.42 & a & 5.29 & $a b$ & 15.69 & a & 15.72 & $a$ & 22.63 & $a$ \\
\hline & T4 & 1.44 & a & 3.00 & a & 4.49 & $a b$ & 11.43 & b & 15.69 & a & 19.18 & a \\
\hline \multirow{4}{*}{ DMR (g plant ${ }^{-1}$ ) } & T1 & 0.54 & $a$ & 1.14 & $a$ & 1.19 & $\mathrm{~b}$ & 5.65 & $\mathrm{C}$ & 5.65 & $b$ & 6.11 & $\mathrm{~b}$ \\
\hline & T2 & 1.18 & a & 3.52 & a & 5.25 & a & 19.91 & a & 19.95 & a & 22.11 & $a$ \\
\hline & T3 & 1.09 & a & 2.10 & a & 3.77 & $a b$ & 16.33 & a & 16.33 & a & 18.99 & a \\
\hline & T4 & 1.18 & $\mathrm{a}$ & 2.46 & $\mathrm{a}$ & 2.96 & $a b$ & 10.27 & $\mathrm{~b}$ & 16.30 & $\mathrm{a}$ & 18.16 & $\mathrm{a}$ \\
\hline \multirow{4}{*}{$\mathrm{PH}(\mathrm{cm})$} & T1 & 13.71 & $\mathrm{a}$ & 15.72 & $\mathrm{a}$ & 18.17 & C & 29.20 & $\mathrm{~b}$ & 37.05 & $\mathrm{~b}$ & 47.59 & $a$ \\
\hline & T2 & 15.40 & a & 19.39 & a & 24.25 & $a b$ & 34.82 & a & 37.21 & b & 54.30 & $a b$ \\
\hline & T3 & 15.25 & a & 18.36 & a & 22.90 & $b c$ & 36.10 & a & 47.17 & a & 56.89 & $\mathrm{a}$ \\
\hline & T4 & 15.72 & a & 15.86 & $\mathrm{a}$ & 28.95 & $\mathrm{a}$ & 36.08 & a & 46.44 & a & 51.60 & b \\
\hline \multirow{4}{*}{$\mathrm{RL}(\mathrm{cm})$} & T1 & 5.80 & a & 5.72 & a & 6.19 & b & 6.44 & b & 6.54 & c & 10.13 & b \\
\hline & T2 & 5.94 & a & 7.81 & a & 8.82 & a & 8.89 & a & 10.72 & b & 16.46 & $a$ \\
\hline & T3 & 6.68 & a & 7.76 & a & 8.57 & $a b$ & 9.18 & a & 15.39 & a & 12.57 & b \\
\hline & T4 & 5.81 & a & 7.91 & a & 8.91 & $a$ & 9.15 & a & 12.95 & $a b$ & 15.57 & a \\
\hline \multirow{4}{*}{ LA $\left(\mathrm{cm}^{2}\right.$ plant $\left.^{-1}\right)$} & T1 & 6.18 & a & 74.47 & $b$ & 92.74 & $b$ & 154.89 & $b$ & 207.10 & $b$ & 216.33 & $b$ \\
\hline & T2 & 14.33 & a & 136.14 & a & 146.73 & a & 155.57 & $b$ & 315.97 & a & 328.63 & a \\
\hline & T3 & 14.41 & a & 117.19 & a & 187.23 & a & 215.98 & a & 316.12 & a & 334.70 & a \\
\hline & $\mathrm{T} 4$ & 16.83 & a & 88.12 & b & 144.34 & a & 196.92 & $a b$ & 316.53 & a & 323.38 & a \\
\hline
\end{tabular}

Means followed by different lowercase letters in the column differ by Tukey test $(p<0.05)$.

Responsible for the interception of solar radiation, a factor that is precursor of photosynthesis, leaf area plays an important role in plant growth and development. The treatments with fipronil + pyraclostrobin + thiophanate-methyl (T2) and thiamethoxam + carbendazim + thiram (T3) showed effects on the leaf area of rice more quickly, when compared to the treatment with imidacloprid + thiodicarb (T4); nonetheless, it is noteworthy that at the end of the evaluations (63 $\mathrm{DAE})$, the same treatments did not differ significantly and showed to be superior than the absence of seed treatment (Table 2).

The dry matter accumulation represents the efficiency with which the plant makes the absorption of energy sources, transforms it into assimilates and accumulates it in plant tissue for later use for its development and growth. The behavior of the dry matter in both the plant fractions, shoot and root, showed great similarity during the course of the experiment. The application of fipronil + pyraclostrobin + thiophanatemethyl (T2) provided the plant faster responses to the addition, comprising superiority already in the early development (Table 2). Therefore, it is understood that seeds treated with pesticides can originate seedlings with a better development and initial growth of their plant structure, through proper solar interception and absorption of nutrients.

The root is an organ of extreme importance in plants due to its function. Its greater performance in growth allows the plant to have a better structure and support on the ground, increased uptake, translocation and assimilation of nutrients by the plant (Sadava, 2009), in addition to being a storage location of energy reserves for some species. According to the observed 
data, it was found that at the end of the evaluations, the applications of the treatments fipronil + pyraclostrobin + thiophanate-methyl (T2) and imidacloprid + thiodicarb (T4) benefited the root growth in rice in relation to the absence of seed treatment. In contrast, no significant difference was found for the application of thiamethoxam + carbendazim + thiram (T3) in relation to the non-application on the increase of the root length (Table 2).

The treatments with agrochemical application showed superiority over the non-application for the variables dry mass of root (DMR), dry mass of shoot (DMS), plant height $(\mathrm{PH})$, root length $(\mathrm{RL})$ and leaf area (LA) (Table 2). These results are consistent with those obtained by Rezende et al. (2003) and Mertz et al. (2009), where they observed positive effect of different treatments of soybean seeds with fungicides. The authors observed that the application of agrochemical fungicides led to higher values in the post-emergence development of soybean seedlings.

The application of seed treatments in rice showed to be efficient against the absence of treatment for the morphophysiological parameters measured. Increases were observed in the main determinants of post-emergence growth and development of the crop, dry mass of shoot (DMS), dry mass of root $(\mathrm{DMR})$, plant height $(\mathrm{PH})$, root length $(\mathrm{RL})$ and leaf area (LA) (Figure 1A, 1B, 1C, 1D and 1E, respectively).
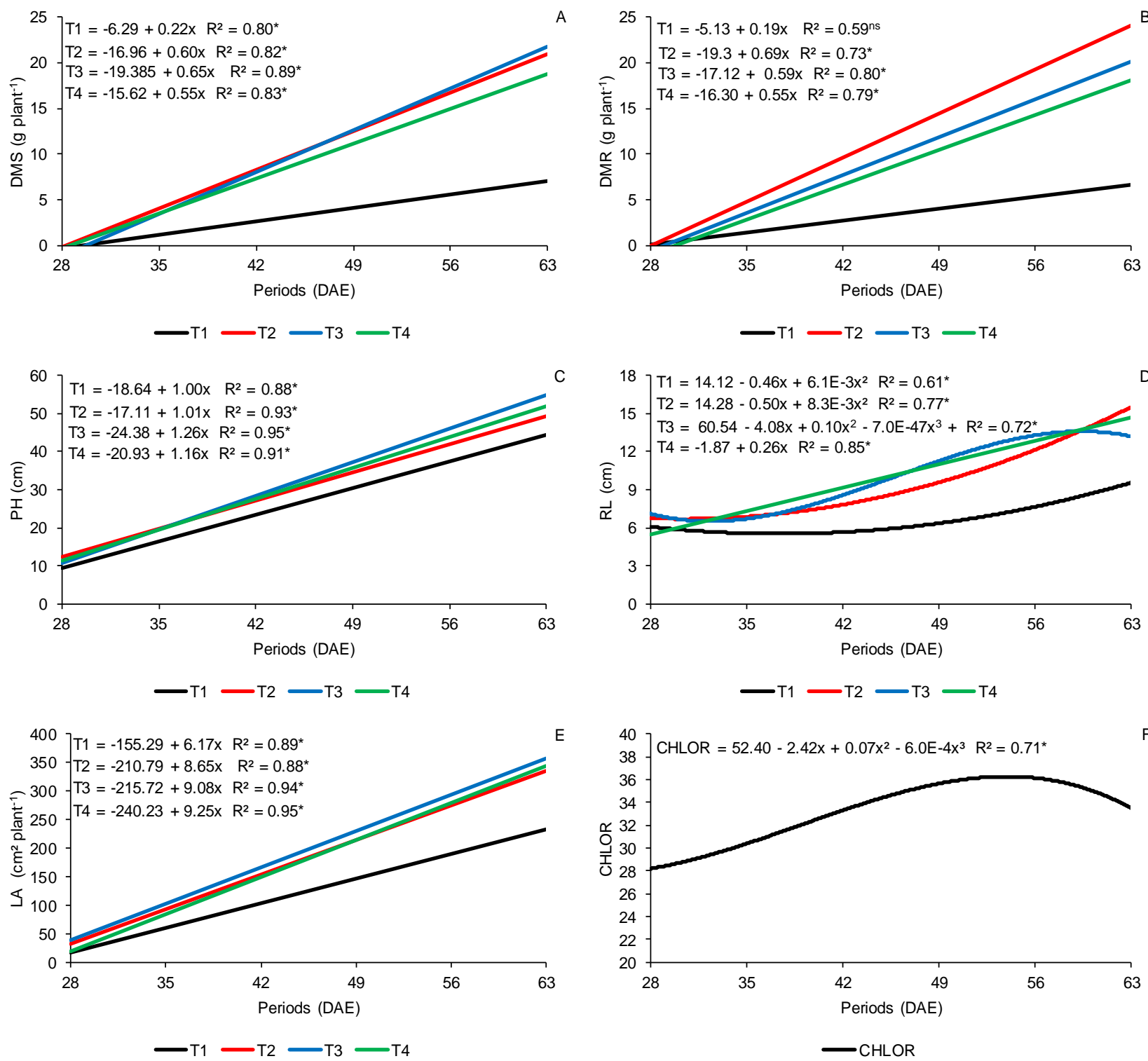

Figure 1 - Regression equations for the effect of different seed treatments on the variables dry mass of shoot (DMS), dry mass of root (DMR), plant height $(\mathrm{PH})$, root length $(\mathrm{RL})$, leaf area $(\mathrm{LA})$ and chlorophyll content (CHLOR) in upland rice, in the city of Frederico Westphalen - RS (2011). *Significant at $5 \%$ error probability by $t$ test. 
Therefore, we emphasize the importance of agrochemical application in the initial period of the rice crop cycle, in order to increase the growth of seedlings and obtain a final plant population that suits the production. Moreover, the work provides subsidies to future research aimed at the application of pesticides in rice cultivation. A fact evident from the wide benefits that these products afford to the crop at an early stage of development.

The chemical treatment did not influence the chlorophyll content, however, there was an increase of it over the days after emergence (Figure 1F). The chlorophyll content of the leaves has a high positive correlation with the nitrogen $(\mathrm{N})$ content in the plant (Madakakze et al., 1999; Argenta et al., 2001, Tian et al., 2011). In this context, Zilli et al. (2009) found no reduction in the nitrogen content in the shoots and neither to soybeans when the seeds were treated with the fungicides carbendazim + thiram and carboxin + thiram, even with a significant reduction in the number of nodes for these treatments. Thus, the author stated that the difference attributed to the development does not interfere with the chlorophyll and nitrogen content in the leaves.

\section{Conclusions}

The use of chemical treatments in upland rice seeds yielded positive effects against all morphological variables observed, except chlorophyll content.

The chemical treatments in seeds corresponded to a differentiation in the post-emergence vegetative development of seedlings for the characteristics dry mass of root, dry mass of shoot, plant height, root length and leaf area, promoting greater initial growth of plants.

\section{References}

Argenta G, Silva PRF, Bortolini CG, Forsthofer EL, Strieder ML (2001) Relação da leitura do clorofilômetro com os teores de clorofila extraível e de nitrogênio na folha de milho. Revista Brasileira de Fisiologia Vegetal 13 (213):158-167.

Benincasa MMP (2004) Análise de Crescimento de Plantas: Noções básicas, FUNEP, Jaboticabal, Brasil. $42 p$.

CONAB - Companhia Nacional de Abastecimento (2013) Acompanhamento da Safra Brasileira de Grãos 2012/13 - Décimo Primeiro Levantamento agosto/2013. Disponível em <http://www.conab.gov.br/ OlalaCMS/uploads/arquivos/13_08_09_10_43_44_bol etim_portuges_agosto_2013_port.pdf >, acesso em 25 de maio de 2015 .

Counce PA, Keisling TC, Mitchell AJ (2000) A uniform, objective, and adaptive system for expressing rice development. Crop Science 40(2):436-443.
Cunha RP, Corrêa MF, Schuch LOB, Oliveira RC, Abreu JS, Silva JDG, Almeida TL (2015) Diferentes tratamentos de sementes sobre o desenvolvimento de plantas de soja. Ciência Rural 45(10):1761-1767.

Elli EF, Caron BO, Monteiro GC, Pavan MA, Pedrassani M, Cantarelli EB, Eloy E (2013) Osmocote no desenvolvimento e comportamento fisiológico de mudas de pitangueira. Comunicata Scientiae 4(4):377384 .

Embrapa - Empresa Brasileira de Pesquisa Agropecuária (2006) Sistema Brasileiro de Classificação de Solos, EMBRAPA-SPI. 412p.

Fan J, Zhang Y, Turner D, Duan Y, Wang D, Shen Q (2010) Root Physiological and Morphological Characteristics of Two Rice Cultivars with Different NitrogenUse Efficiency. Pedosphere 20(4):446-455.

FAO - Food and Agricultural Organization (2009) FAO discute demanda mundial por alimentos. FAO Brasil Notícias. Disponível em $<$ https://www.fao.org.br/FAOddma.asp>, acesso em 25 de maio de 2015.

Fornasieri Filho D, Fornasieri JL (2006) Manual da cultura do arroz, FUNEP. 589p.

Jouki M, Khazaei N (2012) Some physical properties of rice seed (Oriza sativa). The IIOAB Journal 3(4):15-18.

Liu L, Tong H, Xiao Y, Che R, Xu F, Hu B, Lian C, Chu J, Li J, Chu C (2015) Activation of big Grain1 significantly improves grain size by regulating auxin transport in rice. Proceedings of the National Academy of Sciences of the United States of America 112(35):11102-11107.

Madakakdze I, Madakadze R, Peterson PR, Coulman BE, Smith DL (1999) Field evaluation of the chlorophyll meter to predict yield and nitrogen concentration of switch grass. Journal of Plant Nutrition 22(6):1001-1010 .

Martins GM, Toscano LC, Tomquelski GV, Maruyama WI (2009) Inseticidas químicos e microbianos no controle da lagarta-do-cartucho na fase inicial da cultura do milho. Revista Caatinga 22(2):170-174.

Menezes VG, Kalsing A, Mariot CHP, Grohs DS, Freitas TFS (2013). Reduction of seed production of red rice escapes in Clearfield rice. Planta daninha 31(4).

Mertz LM, Henning FA, Zimmer PD (2009) Bioprotetores e fungicidas químicos no tratamento de sementes de soja. Ciência Rural 39(1):13-18.

Mingotte FLC, Gonçalves MHG, Yada MM, Fornasieri Filho D, Lemos LB (2015) Agronomic efficiency and grain quality of upland rice cultivars as a function of nitrogen topdressing. Bioscience Journal 31(3):748-758. 
Pan S, Liu H, Mo Z, Patterson B, Duan M, Tian H, Hu S, Tang X (2016) Effects of Nitrogen and Shading on Root Morphologies, Nutrient Accumulation, and Photosynthetic Parameters in Different Rice Genotypes. Nature: Scientific Reports 6.

Pereira Filho CR, Cobucci T, Nascente AS, Machado AA, Oliveira KGB, Carvalho ABA (2008) Avaliação do efeito do fipronil na produtividade do feijoeiro comum. Campinas: IAC, 4p. (Documentos 85).

Pereira LAA, Coutinho WM, Machado JC, Magalhães FHL, Pena RCM (2002) Fungitoxicidade in vitro de iprodione sobre o crescimento micelial de fungos que se associam a sementes de arroz. Revista Brasileira de Sementes 24(1):67-70.

Rezende PM, Machado JC, Gris CF, Gomes LL, Botrel EP (2003) Efeito da semeadura a seco e tratamento de sementes na emergência, rendimento de grãos e outras características da soja [Glycine max (L.) Merrill]. Ciência Agrotécnica 27(1):76-83.

Sadava D (2009) Vida: A Ciência da Biologia - 8.ed.: Volume 3: Plantas e Animais, Artmed. 1432 p.

Salgado FHM, Ximenes PA (2013) Maize seed germination treated with insecticides. Journal of Biotechnology and Biodiversity 4(1):49-54.
Santos FC, Oliveira JÁ, Von Pinho EVR, Guimarães RM, Vieira AR (2010) Tratamento químico, revestimento e armazenamento de sementes de Brachiaria brizantha cv. Marandu. Revista Brasileira de Sementes 32(3):69-78.

SAS Learning Edition (2000) Getting started with the SAS Learning Edition, Cary. 200 p.

Silva CS, Lucca Filho OA, Zimmer PD, Bonini Filho RM (2011) Efeito do tratamento químico sobre a qualidade fisiológica e sanitária de sementes de arroz com diferentes graus de umidade. Revista Brasileira de Sementes 33(3):426-434.

Tian YC, Yao X, Yang J, Cao WX, Hannaway DB, Zhu $Y$ (2011) Assessing newly developed and published vegetation indices for estimating rice leaf nitrogen concentration with ground and space-based hyperspectral reflectance. Field Crops Research 121(3):464.

Villar PM, Ferreira CM (2005) Dinâmicas territoriais do arroz de terras altas na região centro-oeste do Brasil. Cadernos de Ciência \& Tecnologia 22(1):97-107.

Zilli JE, Ribeiro KG, Campo RJ, Hungria M (2009) Influence of fungicide seed treatment on soybean nodulation and grain yield. Revista Brasileira de Ciência do Solo 33(4):917-923. 